\title{
Enhanced Arsenic Removal from Aqueous Solution by Fe/Mn-C Layered Double Hydroxide Composite
}

\author{
Yaru Wang $\mathbb{D}^{1,2}$ Yingying Gao $\mathbb{D}^{1,2}$ Zongqiang Zhu $\mathbb{D}^{1,2,3}$ Lihao Zhang $\mathbb{D}^{1,2}$ \\ Ningning Zhao $\mathbb{D}^{1,2}$, Yali Fang $\mathbb{D}^{1,2}$ Yinian Zhu $\mathbb{D}^{1,2}$ and Guifeng Liu $\mathbb{D}^{1,2}$ \\ ${ }^{1}$ Collaborative Innovation Center for Water Pollution Control and Water Safety in Karst Area, Guilin University of Technology, \\ Guilin 541004, China \\ ${ }^{2}$ Guangxi Key Laboratory of Environmental Pollution Control Theory and Technology, Guilin University of Technology, \\ Guilin 541004, China \\ ${ }^{3}$ Research Center for Eco-Environmental Sciences, Chinese Academy of Sciences, Beijing 100085, China
}

Correspondence should be addressed to Zongqiang Zhu; zhuzongqiang@glut.edu.cn and Lihao Zhang; lhzhang@glut.edu.cn

Received 29 September 2020; Revised 25 November 2020; Accepted 13 December 2020; Published 9 January 2021

Academic Editor: Hai Nguyen Tran

Copyright (c) 2021 Yaru Wang et al. This is an open access article distributed under the Creative Commons Attribution License, which permits unrestricted use, distribution, and reproduction in any medium, provided the original work is properly cited.

\begin{abstract}
A novel material named Fe/Mn-C layered double hydroxide composite (Fe/Mn-C-LDH) was synthesized to remove arsenic from an aqueous solution. The removal performance of the composite toward arsenic ions was studied through the batch experiments. The experiment results showed that Fe/Mn-C-LDH exhibited a high adsorption capacity of $46.47 \mathrm{mg} / \mathrm{g}$ for As(III) and $37.84 \mathrm{mg} / \mathrm{g}$ for $\mathrm{As}(\mathrm{V})$ at $318 \mathrm{~K}$, respectively. In addition, the investigation of the release of $\mathrm{Fe}^{3+}$ and $\mathrm{Mn}^{2+}$ in the process of arsenic adsorption revealed that the Fe/Mn-C-LDH exhibited better stability than Fe/Mn-layer double hydroxide (Fe/Mn-LDH) with fewer $\mathrm{Mn}^{2+}$ and $\mathrm{Fe}^{3+}$ releasing under the same condition. The BET results showed that the specific surface area of Fe/Mn-C-LDH decreased after adsorption of As (III) and As (V). Furthermore, the Density Functional Theory (DFT) calculation results proved that the adsorbent combining arsenic by T-site to produce a better adsorption effect for arsenic. Possessing better stability and adsorption capacity, Fe/Mn-C-LDH could potentially serve as a perfect adsorbent for arsenic removal from an aqueous environment. It would provide a promising approach for removing heavy metal from the aquatic environment in the future.
\end{abstract}

\section{Introduction}

As one of the highly poisonous and hazardous heavy metal elements in water, arsenic mainly occurred in the forms of $\mathrm{As}(\mathrm{III})$ and $\mathrm{As}(\mathrm{V})$ in the natural water environment [1-5]. $\mathrm{As}(\mathrm{V})$ is dominant in oxidizing conditions and mainly exists in the form of $\mathrm{H}_{2} \mathrm{AsO}_{4}{ }^{-}$and $\mathrm{HAsO}_{4}{ }^{2-}$, and $\mathrm{As}(\mathrm{III})$ principally as $\mathrm{H}_{3} \mathrm{AsO}_{3}$ [6]. Typically, $\mathrm{As}(\mathrm{III})$ is more difficult to be removed from wastewater or aquatic environment [6]. In order to ensure people's health unaffected by arsenic, WHO stipulated that the maximum permissible limit of arsenic is $10 \mu \mathrm{g} / \mathrm{L}$ [7-9]. Therefore, it is urgent to develop a facile and highly effective method to remove arsenic from the aquatic environment efficiently. Adsorption, being considered as one of the most prospective approaches for removing arsenic, has the advantages of eco-friendly, high efficiency, and low cost $[7,10]$. Many sorbent materials have been developed to scavenge arsenic from an aqueous environment [11]. Natural and synthetic materials in the literature mainly included activated carbon [12], activated alumina [13], biological adsorbents [14], and mineral adsorbents [15]. However, the poor performance in terms of adsorption capability and posttreatment separation have restricted their application. In recent years, the biochar and layered double hydroxides (LDHs) have drawn considerable attention in the scientific community because of their stability, large surface area, porous structure, and functional group [16], which have been widely applied as adsorbents in sewage treatment [17]. The arsenic adsorption capacity of biochar was heavily influenced by functional groups with a positive charge and ions on the surface because arsenic existed in the form of an anion in an aqueous solution [18]. LDH, as a kind of typical clay 
inorganic material $[19,20]$, and its special formula could be noted as $\left[\mathrm{M}_{1-\mathrm{x}}{ }^{2+} \mathrm{M}_{\mathrm{x}}{ }^{3+}(\mathrm{OH})_{2}\right]^{\mathrm{x}+}\left(\mathrm{A}^{\mathrm{n}-}\right)_{\mathrm{x} / \mathrm{n}} \cdot \mathrm{yH}_{2} \mathrm{O}$, in which $\mathrm{M}^{3+}$ and $\mathrm{M}^{2+}$ are the divalent and trivalent cations, respectively. $A$ represents a charge balancing anion in the interlay, $n$ is the valence anion of the interlayer, and $x$ denotes the density of charge, varying from $0.17 \sim 0.33$ in general [21-25]. Because LDHs are rich in hydroxyl groups and interlayer anions, they can accommodate different ions in their structure [19]. However, the removal capacities of LDHs are limited by their morphology in water and the bulk/particle structure and multilayer packing. The biochar derived from bamboo could offer a substrate for loading LDHs and expand the surface area of the adsorbent to achieve better adsorption efficiency for heavy metals [26]. Consequently, synthesizing the bamboo biochar/LDHs is of great significance to remove arsenic from polluted wastewater effectively. Furthermore, the stability of the adsorbent should be taken into consideration, and it should be environmentally friendly after recycling.

Herein, scanning electron microscope (SEM), X-ray diffraction (XRD), Fourier transform infrared spectrophotometer (FTIR), X-ray photoelectron spectroscopy (XPS), and Brunner Emmett teller (BET) were applied to characterize the microstructure of Fe/Mn-C-LDH in this research. The adsorption capacity for arsenic was examined as well as the metal ion concentration in water solution after adsorption. Moreover, Density Functional Theory was applied to reveal the adsorption removal mechanism. All these provide a promising avenue for the application prospect of Fe/Mn-C$\mathrm{LDH}$ to remove arsenic ions from the aqueous environment.

\section{Method and Experiment}

2.1. Materials. The details of the materials are listed in Text S1.

2.2. Method and Characterization of Fe/Mn-C-LDH. The barks of the bamboo pieces after drying were peeled off and soaked in $5 \%$ ammonia water for $6 \mathrm{~h}$ at $100^{\circ} \mathrm{C}$. Followed by $2 \mathrm{~h}$ ultrasonication, the pieces were washed using ultrapure water and dried at $80^{\circ} \mathrm{C}$. Afterwards, the pieces were roasted in a muffle furnace for $3 \mathrm{~h}$, crushed, and sifted to obtain bamboo biochar powder. About $50 \mathrm{~g}$ bamboo charcoal powder and $250 \mathrm{~mL}$ concentrated nitric acid were added into a flask, boiled with stirring in an oil bath at $110^{\circ} \mathrm{C}$ for $6 \mathrm{~h}$. After washing to neutral and dried, the bamboo charcoal powder was added into a beaker containing ultrapure water and stirred with a magnetic stirrer to obtain carbon/water mixture. The $\mathrm{pH}$ was adjusted to 10 with a mixed alkali solution of sodium hydroxide and sodium carbonate. Meanwhile, under violent stirring, the mixed metal chloride $\left(\mathrm{Mn}^{2+}: \mathrm{Fe}^{3+}=2: 1\right)$ and the mixed alkali solution were added drop-wisely into the carbon/water mixture simultaneously at $40^{\circ} \mathrm{C}$ with the $\mathrm{pH}$ keeping constant (about 10). Subsequently, the mixture was aged in a water bath of $40^{\circ} \mathrm{C}$ for $24 \mathrm{~h}$. After the mixture cooled down to room temperature, the precipitate was filtered and washed with ultrapure water. Finally, the Fe/Mn-C-LDH was obtained through drying vacuum freeze-drying.
2.3. Characterization. The details of the characterization of $\mathrm{Fe} / \mathrm{Mn}-\mathrm{C}-\mathrm{LDH}$ are presented in Text S2.

2.4. Adsorption Experiment. The adsorption experiment of arsenic by Fe/Mn-C-LDH was performed according to the controlled variable method. For kinetics study, $70 \mathrm{mg}$ adsorbent was added into $50 \mathrm{~mL}$ arsenic solutions with a concentration of $5 \mathrm{mg} / \mathrm{L}, 10 \mathrm{mg} / \mathrm{L}$, and $50 \mathrm{mg} / \mathrm{L}$, respectively. The appropriate adsorption time intervals were regulated from 1 to $1440 \mathrm{~min}\left(T=25^{\circ} \mathrm{C}\right)$. For the isotherms, the experiments were done with $T=25^{\circ} \mathrm{C}, 35^{\circ} \mathrm{C}$, and $45^{\circ} \mathrm{C}$, and the concentration of the arsenic solutions ranged from 5 to $100 \mathrm{mg} / \mathrm{L}$. The initial $\mathrm{pH}$ value of the solutions was adjusted from 2 to 11 .

The adsorption capacity in the adsorption experiment could be calculated by Eq.(1) [27].

$$
Q_{\mathrm{e}}=\frac{V\left(C_{0}-C_{\mathrm{e}}\right)}{m},
$$

where $m$ (mg) represents the weight of the adsorbent and $V(\mathrm{~mL})$ denotes the suspension volume. $C_{0}$ and $C_{\mathrm{e}}$ are the initial and equilibrium solute concentration, respectively.

The Langmuir (Eq.(2)) and Freundlich (Eq.(3)) models have been used to simulate the adsorption isotherms [8, 28]. Temkin (Eq.(4)) isotherm represents the binding equilibrium between adsorbates and adsorbents [29].

$$
\begin{aligned}
\frac{C_{\mathrm{e}}}{Q_{\mathrm{e}}} & =\frac{1}{K_{\mathrm{L}} Q_{\mathrm{m}}}+\frac{C_{\mathrm{e}}}{Q_{\mathrm{m}}}, \\
\ln Q_{\mathrm{e}} & =\frac{1}{n} \ln C_{\mathrm{e}}+\ln K_{\mathrm{f}}, \\
Q_{\mathrm{e}} & =A+B \log C_{\mathrm{e}},
\end{aligned}
$$

where $C_{\mathrm{e}}(\mathrm{mg} / \mathrm{L})$ is the equilibrium concentration of arsenic; $Q_{\mathrm{m}}(\mathrm{mg} / \mathrm{g})$ represents the maximum uptake capacity; $n$ is the Freundlich parameter; $K_{\mathrm{L}}$ and $K_{\mathrm{f}}$ are the Langmuir and Freundlich adsorption coefficients, respectively; $A(\mathrm{~L} / \mathrm{g})$ is the equilibrium constant; and $B(\mathrm{~J} / \mathrm{mol})$ is the constant with the heat of sorption in Temkin. Generally, a high value of $B$ favors a chemisorption mechanism [30].

The adsorption kinetics can be elaborated by the pseudofirst-order (Eq. (5)) and pseudo-second-order (Eq. (6)) kinetic models [31] to calculate the adsorption rate,

$$
\begin{aligned}
\ln \left(Q_{\mathrm{e}}-Q_{\mathrm{t}}\right) & =\ln Q_{\mathrm{e}}-k_{1} t, \\
\frac{t}{Q_{\mathrm{t}}} & =\frac{1}{k_{2} Q_{\mathrm{e}}{ }^{2}}+\frac{t}{Q_{\mathrm{e}}},
\end{aligned}
$$

where $Q_{t}(\mathrm{mg} / \mathrm{g})$ represents the amount of arsenic uptake capacity at time $t ; k_{1}$ and $k_{2}$ are the rate constants.

\section{Results and Discussion}

\subsection{Characterization of Fe/Mn-C-LDH}

3.1.1. SEM-EDS. The SEM-EDS images of raw biochar and $\mathrm{Fe} / \mathrm{Mn}-\mathrm{C}-\mathrm{LDH}$ are shown in Figure 1. The results obviously suggested that raw biochar had a porous structure [32]. Also, 


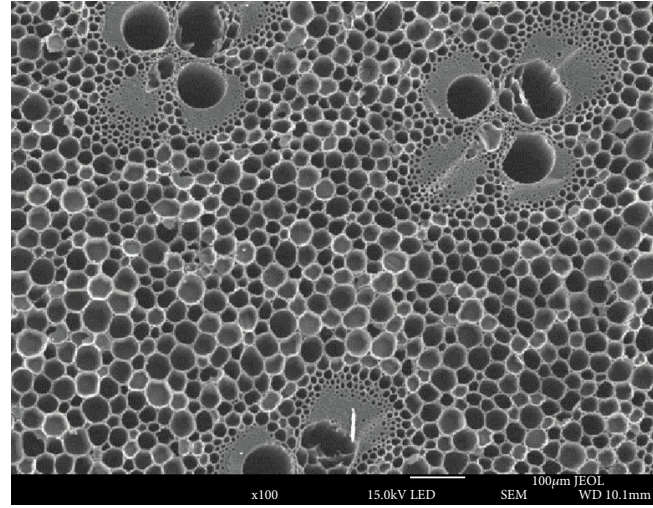

(a)

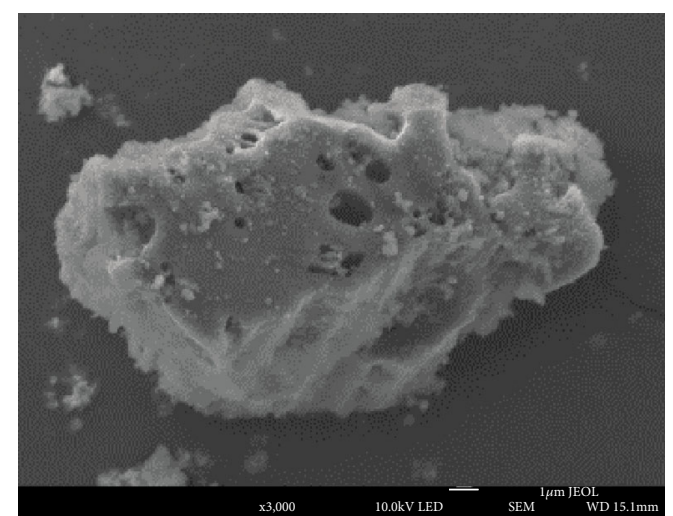

(b)

Figure 1: SEM of C (a) and Fe/Mn-C-LDH (b).

TABLe 1: The content of the element in Fe/Mn-C-LDH.

\begin{tabular}{lcccc}
\hline Elements & $\mathrm{C}$ & $\mathrm{O}$ & $\mathrm{Fe}$ & $\mathrm{Mn}$ \\
\hline Content (\%) & 13.42 & 47.04 & 26.96 & 12.58 \\
\hline
\end{tabular}

the surface of biochar was covered with many particles, regarded as the flake-structured LDH distinctly observed in Figure 1(b) (Figure S1c).

The flake structure and layered structure observed in Figure S1d and Figure S1e were typical LDH morphologies. The EDS spectrum results (Figure S1f) showed that there contain $13.42 \%$ carbon in Fe/Mn-C-LDH (the specific content is shown in Table 1). Besides, the ratio of $\mathrm{Mn}$ to $\mathrm{Fe}$ was close to $2: 1$ in adsorbent, indicating that the Fe/Mn-CLDH was synthesized successfully. It can be seen from Figure S1g and Figure S1h that after Fe/Mn-C-LDH adsorbs $\mathrm{As}(\mathrm{III})$ and $\mathrm{As}(\mathrm{V})$, the flake grains are flattened and piled up, resulting in agglomeration compared with that before adsorption.

3.1.2. XRD. The powder XRD was used to characterize the $\mathrm{Fe} / \mathrm{Mn}-\mathrm{C}-\mathrm{LDH}$, with a scanning range of $10 \sim 80^{\circ}$. The $\mathrm{C}$ has a relatively wide shoulder peak at $2 \theta=24.78^{\circ}, 42.48^{\circ}$, and no other obvious diffraction peaks are found, mainly due to its low crystallization degree and amorphous structure. The pattern of Fe/Mn-C-LDH exhibited a peak at $11.65^{\circ}$, which was the characteristic peak of Fe/Mn-C-LDH structure along with the intercalated anion of $\mathrm{CO}_{3}{ }^{2-}$ [33], indicating that $\mathrm{Fe} / \mathrm{Mn}-\mathrm{C}-\mathrm{LDH}$ was successfully prepared. Besides, the characteristic peaks and metal by products such as $\mathrm{MnCO}_{3}$ appeared at the peak $2 \theta=24.18^{\circ}, 31.32^{\circ}, 35.68^{\circ}, 41.43^{\circ}$, $45.08^{\circ}, 51.54^{\circ}$. It can be seen from Figure 2 that after the adsorption of $\mathrm{As}(\mathrm{III})$, the characteristic diffraction peak of Fe-Mn-C-LDH composite (003) shifts slightly on the high angle position, while the diffraction peak position of metal by-products does not change obviously, indicating that the adsorption of As(III) by Fe-Mn-C-LDH was mainly attributed to $\mathrm{LDH}$ and bamboo charcoal in the adsorbent. After the adsorption of $\mathrm{As}(\mathrm{V})$ by Fe-Mn-C-LDH, the crystal structure changes obviously, the peak (003) shifts to a high angle, and the peak representing metal oxide at $2 \theta=31.30^{\circ}$ disappeared obviously before adsorption, indicating that both $\mathrm{Fe} / \mathrm{Mn}-\mathrm{C}-\mathrm{LDH}$ and some metal oxide have an effect on the adsorption of $\mathrm{As}(\mathrm{V})$. According to the previous adsorption experimental results, the adsorption effect of Fe-Mn/C$\mathrm{LDH}$ for $\mathrm{As}(\mathrm{III})$ was better than that of $\mathrm{As}(\mathrm{V})$, which may be due to the adsorption reaction of some metal oxides instead of Fe-Mn/C-LDH when adsorbing $\mathrm{As}(\mathrm{V})$, so the overall adsorption effect was lower.

3.1.3. XPS. The composition of Fe/Mn-C-LDH was analyzed by XPS before and after arsenic adsorption. The results are presented in Figure 3(a).

The peaks corresponding to $\mathrm{C} 1 \mathrm{~s}, \mathrm{O} 1 \mathrm{~s}, \mathrm{Fe} 2 \mathrm{p}, \mathrm{Mn} 2 \mathrm{p}$, and As $3 \mathrm{~d}$ emerged obviously in the spectrum which indicated the existence of these elements in Fe/Mn-C-LDH. Typically, the peaks at $284.44 \mathrm{eV}, 285.28 \mathrm{eV}$, and $288.56 \mathrm{eV}$ were marked by the $\mathrm{C}-\mathrm{C}, \mathrm{C}-\mathrm{O}$, and $\mathrm{C}=\mathrm{O}$ bonds, respectively [34], indicating the bond energy position change slightly after arsenic adsorption. The XPS spectrum of the As(III) after treatment exhibited two peaks at $43.65 \mathrm{eV}$ and $44.58 \mathrm{eV}$. This shows that part of As(III) was oxidized to $\mathrm{As}(\mathrm{V})$ by $\mathrm{Fe} / \mathrm{Mn}-\mathrm{C}-\mathrm{LDH}$ in the process of adsorbing As(III) [8]. However, in the process of adsorbing As $(\mathrm{V})$, only one As $3 \mathrm{~d}$ peak arose at $44.32 \mathrm{eV}$, which was ascribed to the $\mathrm{As}(\mathrm{V})-\mathrm{O}$ bonding. There were three forms of $\mathrm{O}\left(\mathrm{O}^{2-},-\mathrm{OH}\right.$ and $\left.\mathrm{H}_{2} \mathrm{O}\right)$ in $\mathrm{Fe} / \mathrm{Mn}-\mathrm{C}-\mathrm{LDH}$ presented in Figure 3(d). The change of bond energy position before and after arsenic adsorption illustrated that coordination exchange could have occurred between arsenate and functional groups of Fe/Mn-C-LDH.

3.1.4. FTIR. The FTIR spectrum of Fe/Mn-C-LDH and biochar before and after arsenic adsorption are presented in Figure 4. For biochar, the band at 3428.95 and $1629.61 \mathrm{~cm}^{-1}$ were emphasized to $\mathrm{H}-\mathrm{O}$ scaling and bending vibration of interlayer water $(\delta \mathrm{H}-\mathrm{O}-\mathrm{H})[19]$. The peaks at about 568.92 and $858.21 \mathrm{~cm}^{-1}$ were marked to the $\mathrm{Fe}-\mathrm{O}$ and $\mathrm{Mn}-\mathrm{O}$ vibration of $\mathrm{Fe} / \mathrm{Mn}-\mathrm{C}-\mathrm{LDH}$, demonstrating that $\mathrm{Fe}$ and $\mathrm{Mn}$ had been loaded on biochar; the absorption peaks of $\mathrm{Mn}-\mathrm{O}$ and $\mathrm{Fe}-\mathrm{O}$ shifted before and after adsorption, indicating that $\mathrm{Mn}-\mathrm{O}$ and $\mathrm{Fe}-\mathrm{O}$ were involved in the adsorption process 


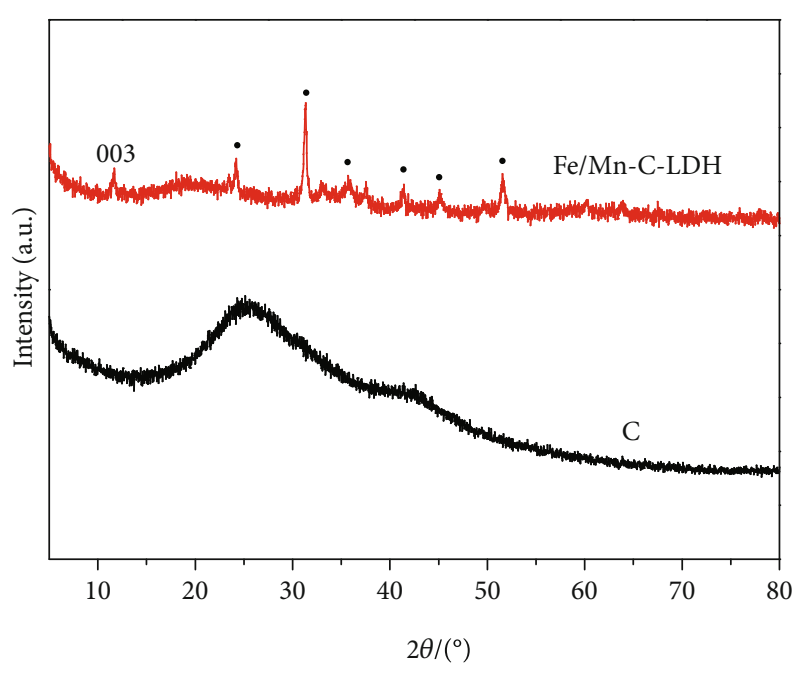

(a)

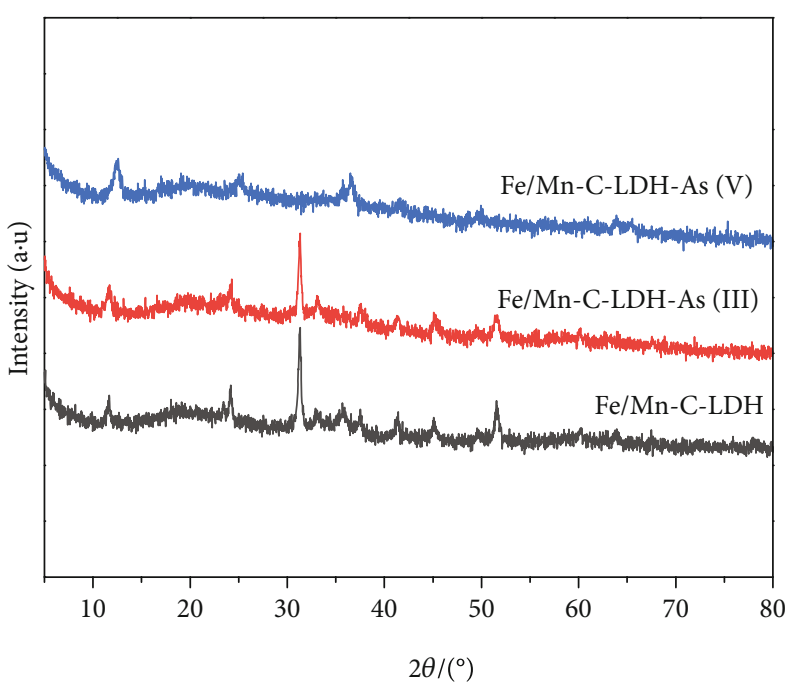

(b)

Figure 2: XRD patterns of C and Fe/Mn-C-LDH.

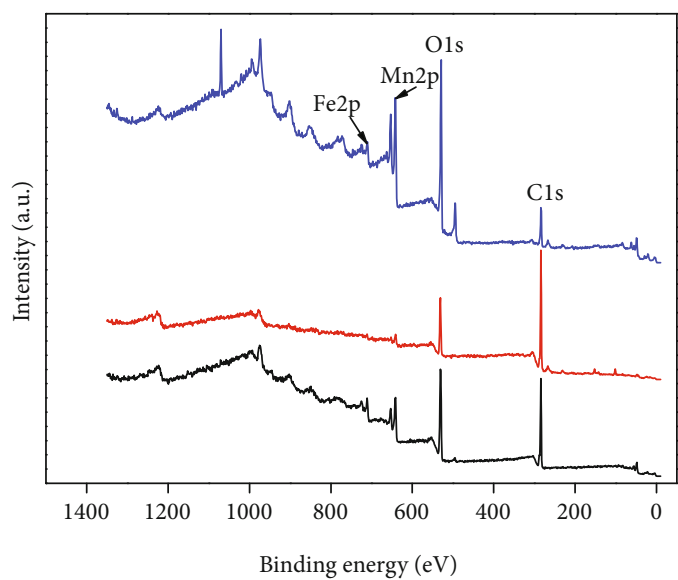

- Fe/Mn-C-LDH-As (V)

— Fe/Mn-C-LDH-As (III)

- Fe/Mn-C-LDH

(a)

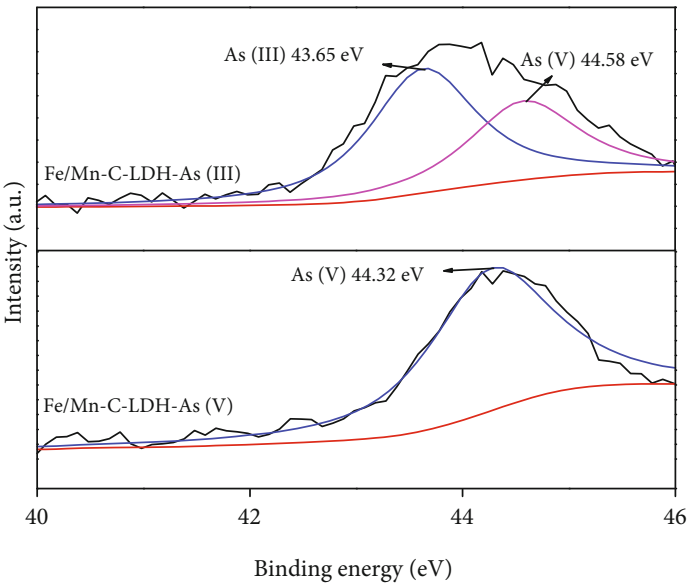

(c)

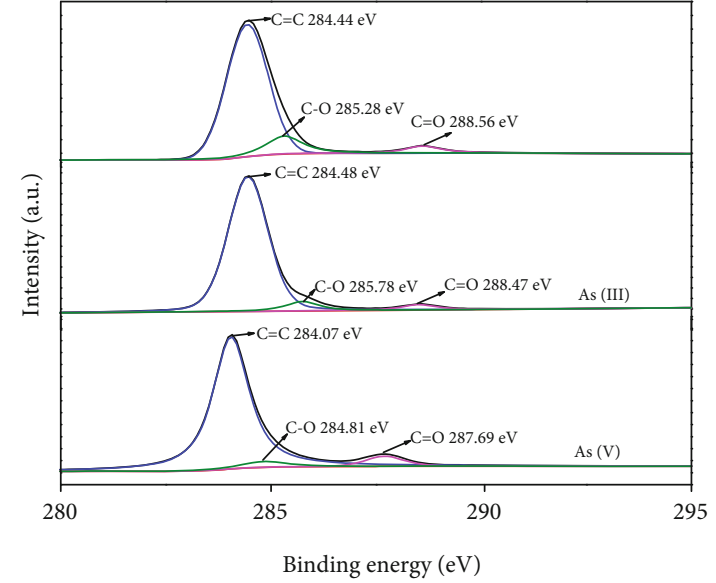

(b)

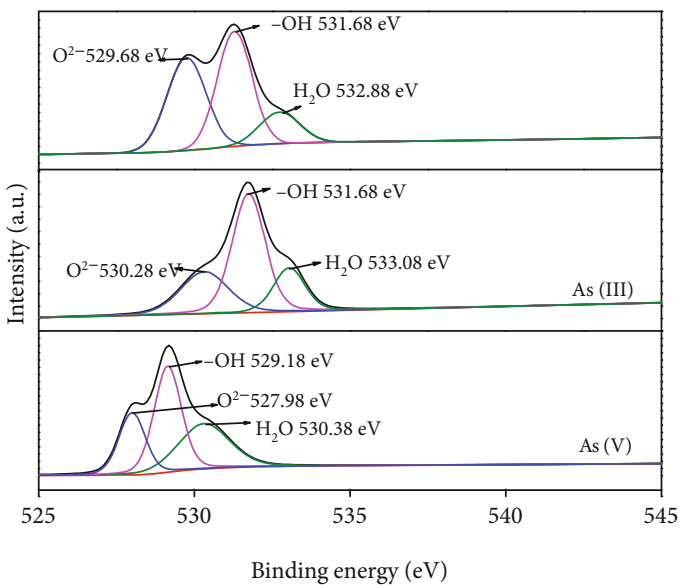

(d)

Figure 3: XPS spectra of survey (a), C 1s (b), As 3d (c), and O 1s (d) of Fe/Mn-C-LDH. 


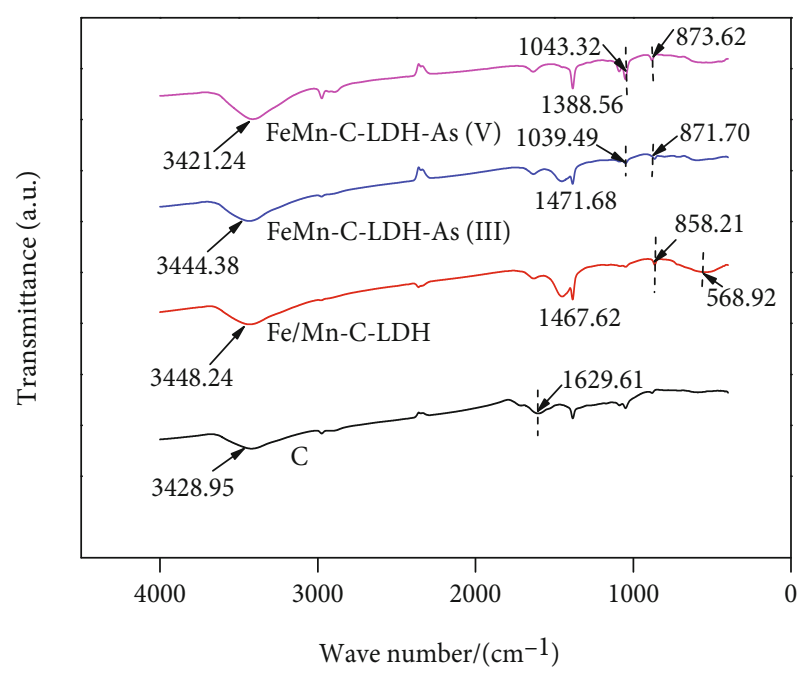

FIgUre 4: The FTIR of C and Fe/Mn-C-LDH with As adsorption.

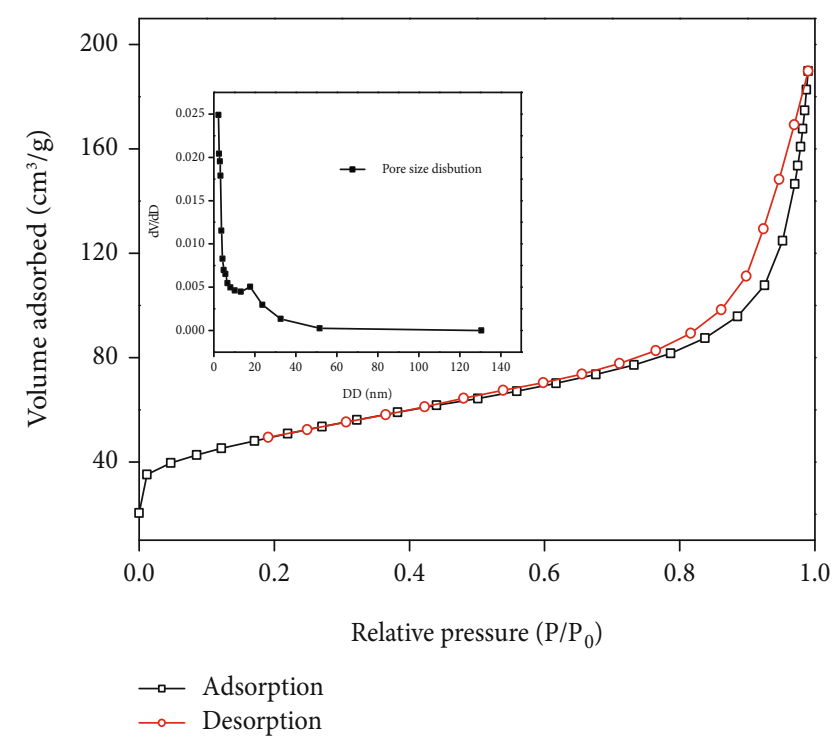

Figure 5: $\mathrm{N}_{2}$ adsorption-desorption curves of Fe/Mn-C-LDH.

$[30,35,36]$. The broad absorption band before arsenic adsorption at $1467.62 \mathrm{~cm}^{-1}$ was assigned to the antisymmetric stretching mode of $\mathrm{CO}_{3}{ }^{2-}$ groups [32]. Two peaks emerged at 1043.32 and $1039.49 \mathrm{~cm}^{-1}$ after arsenic adsorption, which was attributed to the asymmetric stretching vibration of the As-O bond [30].

3.1.5. BET. Nitrogen adsorption-desorption isotherms at $77 \mathrm{~K}$ for $\mathrm{Fe} / \mathrm{Mn}-\mathrm{C}-\mathrm{LDH}$ are revealed in Figure 5. According to the IUPAC classification, Fe/Mn-C-LDH followed type IV isotherm with $\mathrm{H}_{3}$ hysteresis loop indicating that $\mathrm{Fe} / \mathrm{Mn}$ $\mathrm{C}-\mathrm{LDH}$ is layered materials. It can be seen from the diagram that the pore size of the material is mainly concentrated in the range of $2 \sim 50 \mathrm{~nm}$, indicating that the material is mesoporous.

According to the data in Table 2, Fe/Mn-C-LDH has a larger specific surface area than $\mathrm{Fe} / \mathrm{Mn}-\mathrm{LDH}$, which is $170.51 \mathrm{~m}^{2} / \mathrm{g}$ and $82.61 \mathrm{~m}^{2} / \mathrm{g}$, respectively, which proves that
TABLE 2: BET surface and pore volume of Fe/Mn-LDH before and after adsorption.

\begin{tabular}{lcc}
\hline Material & $\begin{array}{c}\text { BET surface } \\
\left(\mathrm{m}^{2} / \mathrm{g}\right)\end{array}$ & $\begin{array}{c}\text { Pore volume } \\
\left(\mathrm{cm}^{3} / \mathrm{g}\right)\end{array}$ \\
\hline Fe/Mn-LDH & 80.61 & 0.21 \\
Fe/Mn-C-LDH & 170.51 & 0.29 \\
$\begin{array}{l}\text { Fe/Mn-C-LDH-As } \\
\text { (III) }\end{array}$ & 68.15 & 0.34 \\
Fe/Mn-C-LDH-As (V) & 92.14 & 0.60 \\
\hline
\end{tabular}

the introduction of biochar increases the specific surface area of the adsorbent; after the adsorption of As(III) and As(V), the specific surface area decreased, which shows that $\mathrm{Fe} / \mathrm{Mn}-\mathrm{C}-\mathrm{LDH}$ is an adsorbent with excellent performance.

\subsection{Effects}

3.2.1. Initial Solution $\mathrm{pH}$ Value. The effect of $\mathrm{pH}$ on the removal of arsenic from aqueous solution using Fe/Mn-CLDH is explained in Figure 6. The consequences illustrated that the effectiveness of As(III) removal was almost constant under acidic and neutral $\mathrm{pH}$ condition. Under the condition of $\mathrm{pH}=2$, the removal efficiency of $\mathrm{As}(\mathrm{III})$ and $\mathrm{As}(\mathrm{V})$ by $\mathrm{Fe} / \mathrm{Mn}-\mathrm{C}-\mathrm{LDH}$ is $98.24 \%$ and $85.33 \%$, respectively. In addition, the adsorption capacity fluctuated when the solution was alkaline, which was due to the repulsion between the electronegative sorbent and dissociated arsenite. $\mathrm{H}_{3} \mathrm{AsO}_{3}$ was the dominant form in the solution through $\mathrm{pH} 9$, while $\mathrm{H}_{2} \mathrm{AsO}_{3}{ }^{2-}$ begin to form at $\mathrm{pH} 10$ and predominating when the solution $\mathrm{pH}$ is in the range of 12.2-13 [17, 37, 38]. In the case of $\mathrm{As}(\mathrm{V})$, the adsorption capacity from the $\mathrm{pH}$ of 2 to 6 remained stable, while from the $\mathrm{pH}$ of 7 to 12 , the capacity decreased gradually. This trend was ascribed to the effect of $\mathrm{pH}$ on the $\mathrm{As}(\mathrm{V})$ uptake mechanism, which was electrostatic attraction when the solution $\mathrm{pH}$ value is below 6 . However, the predominant species of $\mathrm{As}(\mathrm{V})$ are $\mathrm{HAsO}_{4}{ }^{2-}$ and $\mathrm{AsO}_{4}{ }^{3-}$ at the $\mathrm{pH}$ of 6.76 and 11.60 , respectively. Therefore, the negative charge on the material surface enhanced As $(\mathrm{V})$ repulsion, resulting in the weakening of the adsorption effect in alkaline conditions [39].

3.2.2. Leaching of Metal Ions. The concentration of $\mathrm{Fe}^{3+}$ and $\mathrm{Mn}^{2+}$ in the supernatant of $\mathrm{As}(\mathrm{III})$ and $\mathrm{As}(\mathrm{V})$ adsorbed by $\mathrm{Fe} / \mathrm{Mn}-\mathrm{C}-\mathrm{LDH}$ and $\mathrm{Fe} / \mathrm{Mn}-\mathrm{LDH}$ was determined through ICP-OES. The chemical stability of Fe/Mn-C-LDH was investigated by detecting the leaching concentration of $\mathrm{Fe}^{3+}$ and $\mathrm{Mn}^{2+}$ in samples at different $\mathrm{pH}$ value from 2 to 11 . The results presented that there was no $\mathrm{Fe}^{3+}$ detected in the supernatant, and the concentration of $\mathrm{Mn}^{2+}$ is shown in Figure 7 . $\mathrm{Fe} / \mathrm{Mn}-\mathrm{C}-\mathrm{LDH}$ was stable when the initial $\mathrm{pH}$ was greater than 3 (Figure 7). In the process of experiment, the optimal dosage of $\mathrm{Fe} / \mathrm{Mn}-\mathrm{LDH}$ adsorbent was $0.03 \mathrm{~g}$, while $\mathrm{Fe} / \mathrm{Mn}-\mathrm{C}-\mathrm{LDH}$ was $0.07 \mathrm{~g}$. Although the optimal dosage of the Fe/Mn-C-LDH was larger than Fe/Mn-LDH, the leaching of $\mathrm{Mn}^{2+}$ from $\mathrm{Fe} / \mathrm{Mn}$-C-LDH was less serious than the latter. This result indicated that the stability of $\mathrm{Fe} / \mathrm{Mn}-\mathrm{C}$ $\mathrm{LDH}$ had been distinctly improved compared with $\mathrm{Fe} / \mathrm{Mn}$ - 

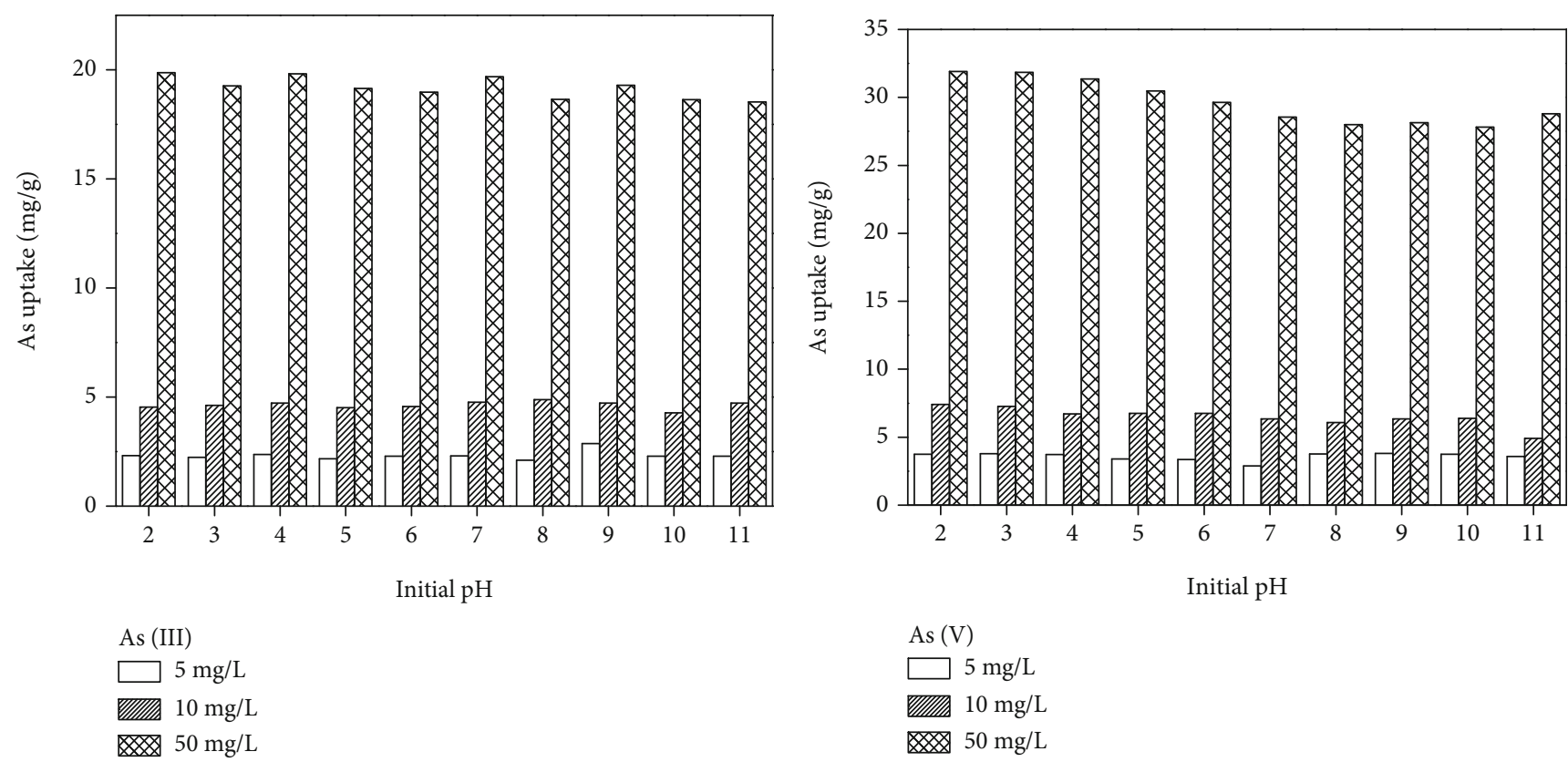

(a)

(b)

Figure 6: Influence of solution $\mathrm{pH}$ on As adsorption capacities on Fe/Mn-C-LDH.

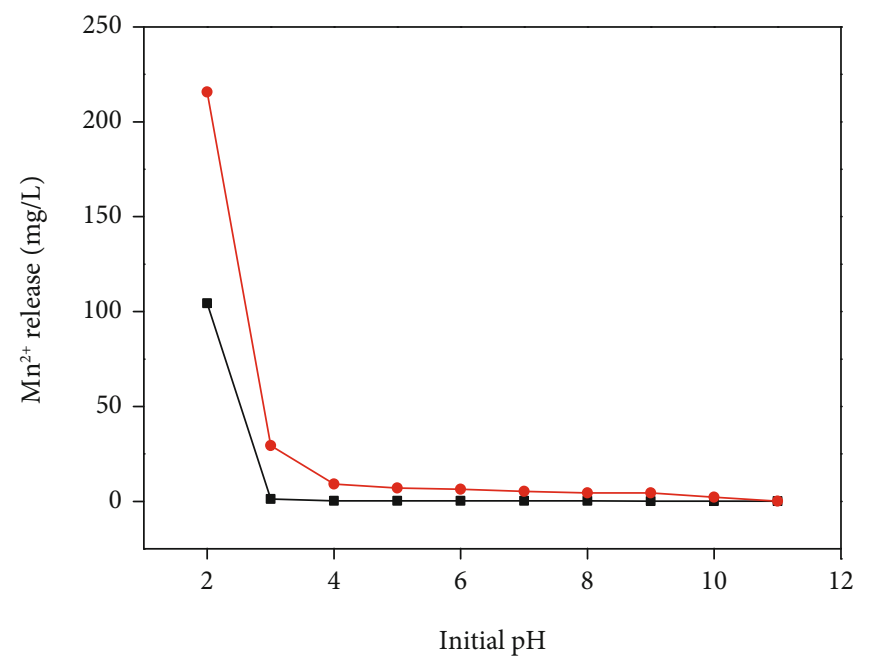

As (III)

$\rightarrow \mathrm{Fe} / \mathrm{Mn}-\mathrm{C}-\mathrm{LDH}$

$\rightarrow \mathrm{Fe} / \mathrm{Mn}-\mathrm{LDH}$

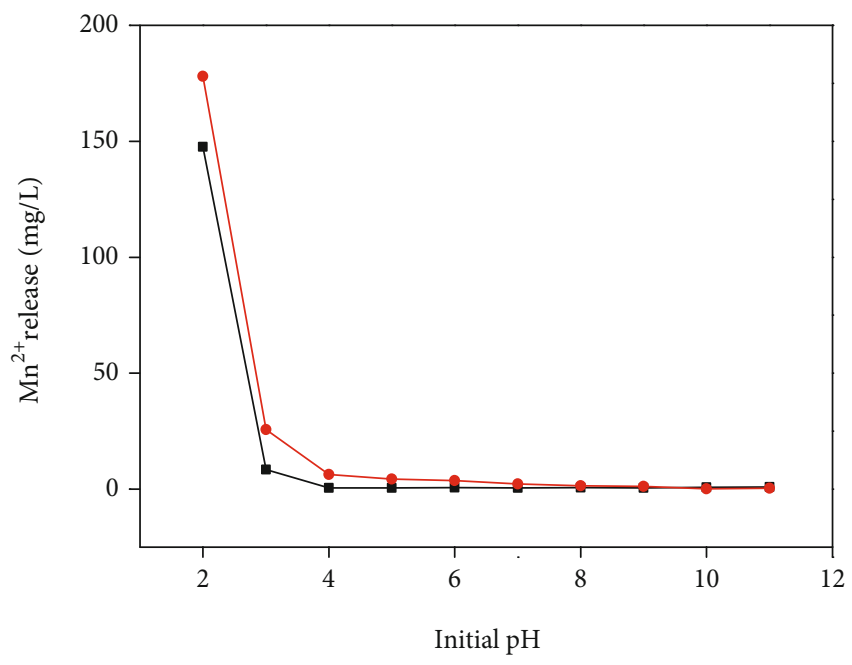

As (V)

$\rightarrow \mathrm{Fe} / \mathrm{Mn}-\mathrm{C}-\mathrm{LDH}$

$\therefore \mathrm{Fe} / \mathrm{Mn}-\mathrm{LDH}$

(a)

(b)

FIGURE 7: $\mathrm{Mn}^{2+}$ concentration in solution at different initial $\mathrm{pH}$.

$\mathrm{LDH}$, mainly because the introduction of alkaline biochar would be served as an effective barrier to prevent/buffer the impact of $\mathrm{H}^{+}$toward LDH nanoparticles [40].

\subsection{Adsorption Isotherms and Kinetics}

3.3.1. Adsorption Isotherms. The adsorption isotherms of $\mathrm{As}(\mathrm{III})$ and $\mathrm{As}(\mathrm{V})$ on $\mathrm{Fe} / \mathrm{Mn}-\mathrm{C}-\mathrm{LDH}$ at $298 \mathrm{~K}, 308 \mathrm{~K}$, and $318 \mathrm{~K}$ are presented in Figure 8 . The adsorption capacity of arsenic on Fe/Mn-C-LDH increased gradually with the initial arsenic concentration increment. The increase of solution diffusion and the decrease of viscosity were the reason of this tendency [41].

The related parameters of Langmuir (Figure 8(b)), Freundlich (Figure S8c), and Temkin (Figure S8d) isotherm models are shown in Table 3. The correlation coefficients $\left(R^{2}\right)$ were obtained through the Langmuir model, which were higher than other models. This phenomenon 




(a)

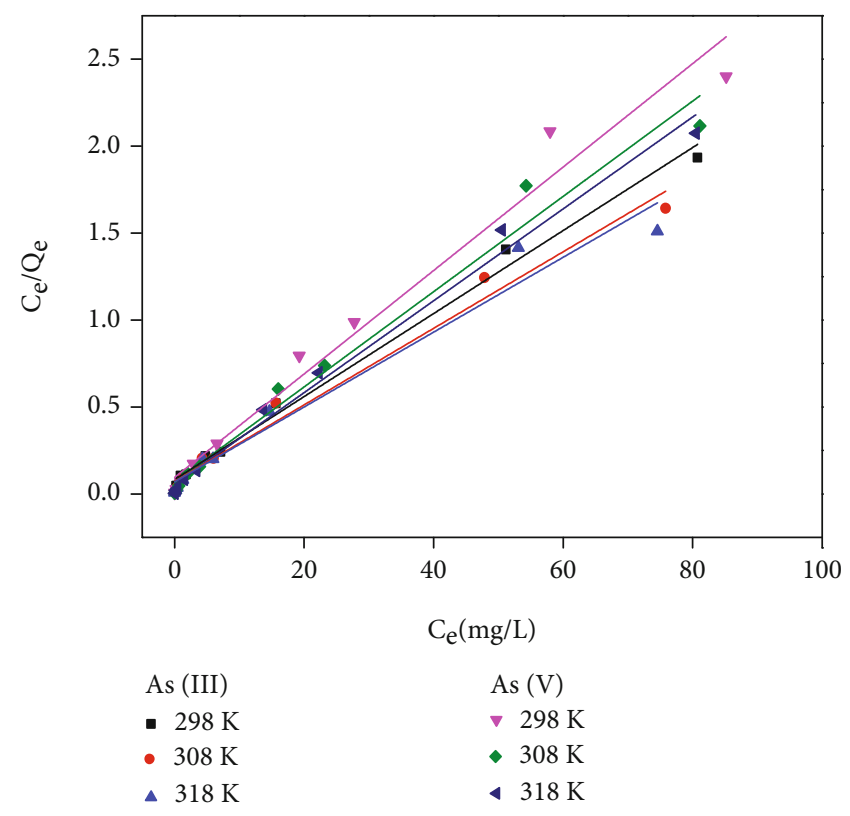

(b)

Figure 8: Adsorption isotherm for arsenic on Fe/Mn-C-LDH.

TABle 3: Langmuir, Freundlich, and Temkin constants for arsenic on Fe/Mn-C-LDH.

\begin{tabular}{ccccccccccc}
\hline & \multirow{2}{*}{$T(\mathrm{~K})$} & \multicolumn{3}{c}{ Langmuir parameters } & \multicolumn{3}{c}{ Freundlich parameters } & \multicolumn{3}{c}{ Temkin parameters } \\
& & $Q_{\mathrm{m}}$ & $K_{\mathrm{L}}$ & $R^{2}$ & $K_{\mathrm{f}}$ & $1 / n$ & $R^{2}$ & $A$ & $R^{2}$ \\
\hline \multirow{3}{*}{ As(III) } & 298 & 41.89 & 0.2897 & 0.9923 & 11.21 & 0.340 & 0.8798 & 13.26 & 14.43 & 0.9631 \\
& 308 & 45.43 & 0.3064 & 0.9821 & 13.67 & 0.294 & 0.9767 & 17.98 & 12.65 & 0.9118 \\
& 318 & 46.47 & 0.3101 & 0.9657 & 13.95 & 0.296 & 0.9723 & 17.30 & 12.50 & 0.9236 \\
& 298 & 33.61 & 0.3133 & 0.9726 & 12.63 & 0.233 & 0.9753 & 15.22 & 8.29 & 0.9396 \\
As(V) & 308 & 36.50 & 0.4066 & 0.9784 & 14.12 & 0.238 & 0.9627 & 17.33 & 9.07 & 0.9417 \\
& 318 & 37.84 & 0.4908 & 0.9896 & 15.12 & 0.236 & 0.9653 & 18.64 & 9.27 & 0.9650 \\
\hline
\end{tabular}

TABLE 4: Thermodynamic parameters of arsenic adsorption by $\mathrm{Fe} / \mathrm{Mn}-\mathrm{C}-\mathrm{LDH}$.

\begin{tabular}{ccccc}
\hline & $T(\mathrm{~K})$ & $\Delta G(\mathrm{~kJ} / \mathrm{Mol})$ & $\Delta H(\mathrm{~kJ} / \mathrm{Mol})$ & $\Delta S(\mathrm{~J} / \mathrm{Mol} / \mathrm{K})$ \\
\hline \multirow{4}{*}{ As(III) } & 298 & -6.19 & & \\
& 308 & -6.47 & 6.81 & 43.74 \\
& 318 & -7.05 & & \\
& 298 & -5.83 & & 94.78 \\
As(V) & 308 & -6.90 & 22.38 & \\
& 318 & -7.73 & & \\
\hline
\end{tabular}

indicated that the arsenic adsorption by Fe/Mn-C-LDH was monolayer adsorption [42, 43].

The thermodynamic parameters of $\mathrm{As}(\mathrm{III})$ and $\mathrm{As}(\mathrm{V})$ adsorption were estimated by Gibbs free energy equation and linearized Van't Hoff equation, which are calculated as follows:

$$
\begin{aligned}
\operatorname{Ln} K_{\mathrm{c}} & =\frac{-\Delta H}{R T}+\frac{\Delta S}{R}, \\
\Delta G & =-R T \operatorname{Ln} K_{\mathrm{c}},
\end{aligned}
$$

where $T$ is temperature $(\mathrm{K})$ and $R$ denotes the molar gas constant. The values of $\Delta H$ and $\Delta S$ were calculated based on the slope and intercept of the straight line of $\mathrm{LnK}_{\mathrm{c}}$ and $1 / \mathrm{T}$. Table 4 showed the values of $\Delta G(\mathrm{~kJ} / \mathrm{mol}), \Delta H(\mathrm{~kJ} / \mathrm{mol})$, and $\Delta S(\mathrm{~J} / \mathrm{mol} / \mathrm{K})$. The negative values of $\Delta G$ implied that the adsorption process was spontaneous. Besides, $\Delta G$ values varying from 0 to $-20 \mathrm{~kJ} / \mathrm{mol}$ manifested a physisorption process [30]. This shows that the adsorption of As(III) and $\mathrm{As}(\mathrm{V})$ by $\mathrm{Fe} / \mathrm{Mn} / \mathrm{C}-\mathrm{LDH}$ is dominated by physical adsorption. It can be seen from the table that $\Delta H>0$, which proves that the reaction is an endothermic process, at the same time also indicating that the whole adsorption process is not complete physical adsorption, but accompanied by chemical adsorption in the physical adsorption process.

3.3.2. Adsorption Kinetics. The arsenic adsorption onto $\mathrm{Fe} / \mathrm{Mn}-\mathrm{C}-\mathrm{LDH}$ at different time was performed (Figure 9(a)).

The uptake of arsenic was a quick process at initial stage and then reached a plateau at $2 \mathrm{~h}$. The loading capacity of As(III) was greater than As(V) under the same conditions; this is because in the solution, As(III) was effectively adsorbed to form an inner complex on the surface of the adsorbent, As(III) existed mainly as a neutral molecule 



$$
\begin{array}{ll}
\text { As (III) } & \text { As }(\mathrm{V}) \\
\because 5 \mathrm{mg} / \mathrm{L} & \rightarrow 5 \mathrm{mg} / \mathrm{L} \\
\rightarrow 10 \mathrm{mg} / \mathrm{L} & \rightarrow-10 \mathrm{mg} / \mathrm{L} \\
\rightarrow-50 \mathrm{mg} / \mathrm{L} & \multimap-50 \mathrm{mg} / \mathrm{L}
\end{array}
$$

\begin{tabular}{|c|c|c|c|c|c|}
\hline \multirow{2}{*}{ Adsorbent } & \multirow{2}{*}{$T\left({ }^{\circ} \mathrm{C}\right)$} & \multirow{2}{*}{$\mathrm{pH}$} & \multicolumn{2}{|c|}{ Sorption $(\mathrm{mg} / \mathrm{g})$} & \multirow{2}{*}{ Reference } \\
\hline & & & As(III) & $\mathrm{As}(\mathrm{V})$ & \\
\hline $\mathrm{NiFe}-\mathrm{LDH}-\mathrm{C}$ & $22 \pm 0.5$ & 7.50 & - & 4.38 & [45] \\
\hline IMIGAC & 30 & 7.50 & 18.4 & 16 & {$[46]$} \\
\hline NMMF & $22 \pm 0.5$ & 8.00 & - & 0.55 & \multirow{2}{*}[47]{} \\
\hline NMMB & $22 \pm 0.5$ & 8.00 & - & 6.52 & \\
\hline MgAl-LDH & 25 & 6.02 & 31.91 & 18.84 & [48] \\
\hline Magnetite-loaded amino-modified microcellulose & 25 & 6.00 & - & 18.5 & [49] \\
\hline $\mathrm{Fe} / \mathrm{Mn}-\mathrm{C}-\mathrm{LDH}$ & 25 & 7.00 & 36.09 & 22.17 & This work \\
\hline
\end{tabular}

(a)

$$
\begin{array}{lc}
\text { As (III) } & \text { As }(\mathrm{V}) \\
\text { - } 5 \mathrm{mg} / \mathrm{L} & \nabla 5 \mathrm{mg} / \mathrm{L} \\
\text { - } 10 \mathrm{mg} / \mathrm{L} & \checkmark 10 \mathrm{mg} / \mathrm{L} \\
\text { \ } 50 \mathrm{mg} / \mathrm{L} & \triangleleft 50 \mathrm{mg} / \mathrm{L}
\end{array}
$$

(b)

Figure 9: Kinetics of arsenic adsorption by Fe/Mn-C-LDH (a). Fitted adsorption isotherms (b).

TABLE 5: The pseudo-first-order and pseudo-second-order models for arsenic on Fe/Mn-C-LDH.

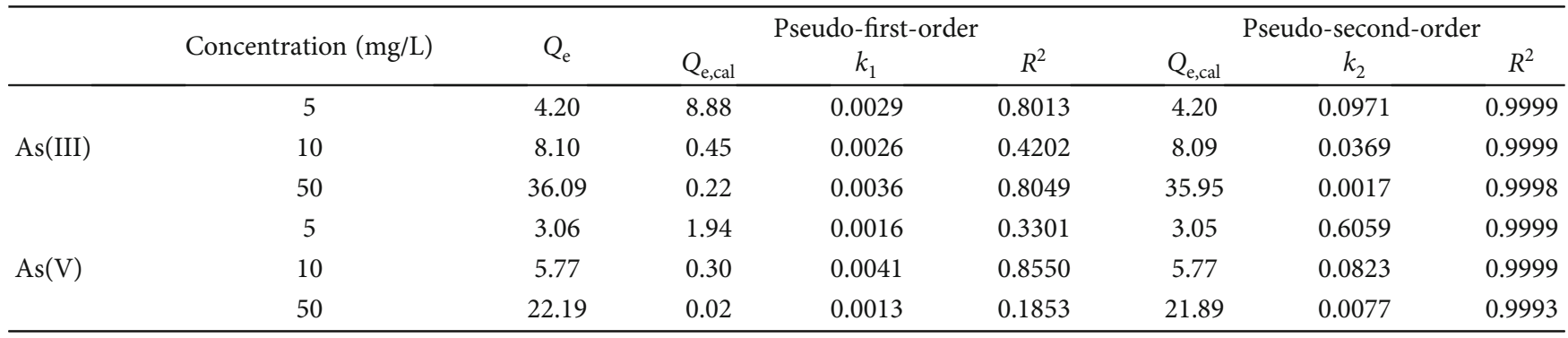

TABLe 6: Comparison among different adsorbent materials for removal As(III) and As(V) from aqueous solutions.

$\left(\mathrm{H}_{3} \mathrm{AsO}_{3}\right)$, which could exchange ligands with the plentiful hydroxyl groups on the surface of the metal laminates, and then As(III) was oxidized to As (V), but for As(V) adsorption, not the oxidized process. Comparing the experimental data with calculated values (Table 5), pseudo-secondorder kinetic model with good correlation coefficient $\left(R^{2}\right)$ was more applicable to explain the adsorption process, and the theoretically maximum capacities calculated based on the pseudo-second-order kinetic model were in good agreement with the experiment data. The adsorption of arsenic could be a chemisorption process, and there were several types of limited adsorption sites on Fe/Mn-CLDH [38, 43, 44].

3.4. Comparison with Literature Data. Table 6 presents a list of different adsorbents that have been used to remove $\mathrm{As}(\mathrm{III})$ and $\mathrm{As}(\mathrm{V})$ from aqueous solutions. The comparison among the materials shows that Fe/Mn-C-LDH 


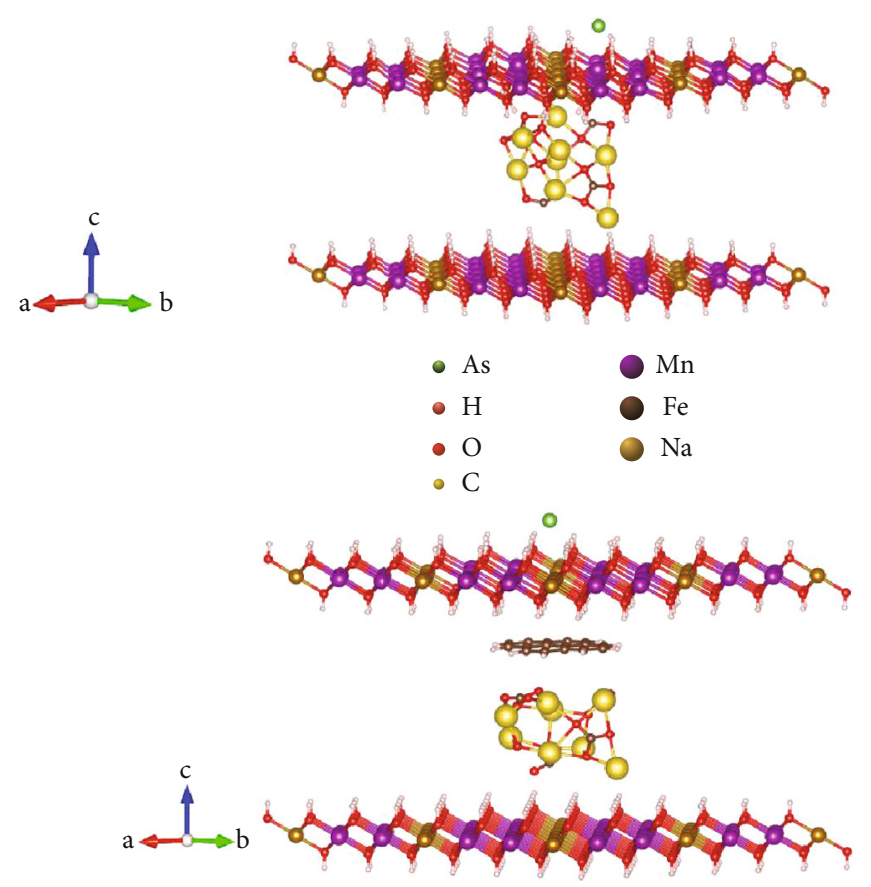

FIgURE 10: Two density functional theory models of the materials.

TABLE 7: Structure parameters in the models.

\begin{tabular}{lccccccc}
\hline \multirow{2}{*}{ Models } & & \multicolumn{3}{c}{ Atomic distances $d(\AA)$ and bond lengths $l(\AA)$} \\
& $d_{\mathrm{Fe}-\mathrm{Mn}}$ & $l_{\mathrm{Mn}-\mathrm{O}}$ & $l_{\mathrm{Fe}-\mathrm{O}}$ & $l_{\mathrm{O}-\mathrm{H}}$ & $l_{\mathrm{C}-\mathrm{O}}$ & $l_{\mathrm{C}-\mathrm{C}}$ & $l_{\mathrm{C}-\mathrm{H}}$ \\
\hline Fe/Mn-LDH & 3.2021 & 2.1633 & 2.1199 & 0.9711 & 1.2971 & - \\
Fe/Mn-C-LDH & 3.2153 & 2.1800 & 2.1403 & 0.9709 & 1.3019 & 1.4194 \\
\hline
\end{tabular}

presents a favourable property. In addition, in the application of removing arsenic pollution in aqueous solution, $\mathrm{Fe} / \mathrm{Mn}-\mathrm{C}-\mathrm{LDH}$ can be used as an efficient adsorbent for arsenic removal.

3.5. DFT Calculation. The adsorption mechanism of arsenic on the Fe/Mn-C-LDH composite was theoretically predicated using DFT method. As shown in Figure 10, the parameters of the unit cell in the model were $a=b=19.301 \AA$, $c=40 \AA ; \alpha=\beta=90^{\circ}, \gamma=120^{\circ}$. Other structural parameters of the main laminates in the Fe/Mn-LDH and Fe/Mn-CLDH samples are shown in Table 7 . The data exhibited that the $\mathrm{Mn}-\mathrm{O}$ and $\mathrm{Fe}-\mathrm{O}$ bond lengths of $\mathrm{Fe} / \mathrm{Mn}-\mathrm{LDH}$ and Fe/Mn-C-LDH were $0.21633,0.21199 \mathrm{~nm}(1 \AA=0.1 \mathrm{~nm})$ and $0.21800,0.21403 \mathrm{~nm}$, respectively. Compared with $\mathrm{Fe} / \mathrm{Mn}-\mathrm{LDH}$, there were more $\mathrm{C}-\mathrm{C}$ and $\mathrm{C}-\mathrm{H}$ bonds in $\mathrm{Fe} / \mathrm{Mn}-\mathrm{C}-\mathrm{LDH}$ laminates, indicating that $\mathrm{C}-\mathrm{C}$ and $\mathrm{C}-\mathrm{H}$ bonds came from the surface functional groups of bamboo charcoal and could participate in the reaction of Fe/Mn-CLDH with arsenic through acupoint adsorption.

DFT functional calculations were performed with VASP (5.5.4). The binding energy was calculated by the following formulation:

$$
E_{\mathrm{b}}=E_{\mathrm{Tot}}-\left(E_{\mathrm{As}}+E_{\mathrm{LDH}}\right) \text {, }
$$

TABle 8: Binding energy of the interaction between $\mathrm{LDH}$ and arsenic.

\begin{tabular}{lcccc}
\hline Models & $E_{\text {Tot }}(\mathrm{eV})$ & $E_{\mathrm{As}}(\mathrm{eV})$ & $E_{\mathrm{LDH}}(\mathrm{eV})$ & $E_{\mathrm{b}}(\mathrm{eV})$ \\
\hline Fe/Mn-LDH & -2368.44 & -1.70 & -2364.41 & -2.33 \\
Fe/Mn-C-LDH & -2545.57 & -1.70 & -2540.91 & -2.96 \\
\hline
\end{tabular}

where $E_{\mathrm{As}}$ is the electron energy of arsenic, $E_{\mathrm{Total}}$ denotes the total energy of the interaction system between arsenic and $\mathrm{Fe} / \mathrm{Mn}-\mathrm{C}-\mathrm{LDH}$, and $E_{\mathrm{LDH}}$ represents the total structure energy of the Fe/Mn-C-LDH material. The parameters used in the calculation process are shown in Table 8.

In the DFT structure of Fe/Mn-LDH and Fe/Mn-C-LDH, the optimized structure of As ion on T-site (directly above $\mathrm{LDH}$ ) was observed [50]. As shown in Figure 10, the presence of $\mathrm{Na}^{+}$has been observed in the structure of both materials; this is because of the ordered positioning of the cations in the layers and the local positive charge distribution; this mismatch of the spatial lead to a net negative charge, which needs to be compensated for by the intercalation of $\mathrm{Na}^{+}$ [51]. The T-site $E_{\mathrm{b}}$ values of As with Fe/Mn-LDH and $\mathrm{Fe} / \mathrm{Mn}-\mathrm{C}-\mathrm{LDH}$ were calculated to be $-2.33 \mathrm{eV}$ and $-2.96 \mathrm{eV}$, respectively. In terms of the binding energy, the sequence of binding affinity surveyed in DFT calculation outcomes proved that the structure of Fe/Mn-C-LDH was more stable than that of Fe/Mn-LDH. 


\section{Conclusions}

In summary, $\mathrm{Fe} / \mathrm{Mn}-\mathrm{C}-\mathrm{LDH}$ has been synthesized and applied to scavenge arsenic in aqueous environment. The pseudosecond-order kinetic model and Langmuir isotherm model can well explain the adsorption processes of arsenic. The adsorption performance of Fe/Mn-C-LDH was prominent at a comparatively wide $\mathrm{pH}$ range for both $\mathrm{As}(\mathrm{III})$ and $\mathrm{As}(\mathrm{V})$. There was no serious $\mathrm{Mn}^{2+}$ release from Fe/Mn-C-LDH in the $\mathrm{pH}$ range from 3 to 11 , lower than the standard limit of GB 18918-2002 (2 mg/L). According to the calculation of Gibbs free energy and Langmuir model, the adsorption processes of arsenic were confirmed to be monolayer adsorption and exothermic reaction. XPS and FTIR researches attested that the exchange of functional groups and arsenic played an essential role in arsenic removal. The specific surface area of $\mathrm{Fe} / \mathrm{Mn}-\mathrm{LDH}$ is $170.508 \mathrm{~m}^{2} / \mathrm{g}$ far more than Fe/Mn-LDH, which proves that the introduction of biochar increases the specific surface area of the adsorbent. DFT results indicated that the adsorbate coordinated with the adsorbent by T-site. Our results demonstrated that the highly stable Fe/Mn-C$\mathrm{LDH}$ might be a promising candidate for arsenic abatement.

\section{Data Availability}

The raw data used to support the findings of this study are available from the corresponding author upon request.

\section{Conflicts of Interest}

The authors declared no potential conflicts of interest with respect to the research, authorship, and/or publication of this article.

\section{Acknowledgments}

This work was financially supported by the National Natural Science Foundation of China (Nos. 21707024, 41763012, and 2019YFC0507502), the Guangxi Science and Technology Planning Project (Nos. GuiKe-AD18126018, GuiKeAA 17204047), the Guangxi Natural Science Foundation (2018GXNSFAA050044), Chinese Postdoctoral Science Foundation (No. 2019M650869), and Innovation Technical Innovation Center of Mine Geological Environmental Restoration Engineering in Southern Karst Area.

\section{Supplementary Materials}

The supplemental material for this article is available online. (Supplementary Materials)

\section{References}

[1] B. K. Mandal and K. T. Suzuki, "Arsenic round the world: a review," Talanta, vol. 58, no. 1, pp. 201-235, 2002.

[2] M. Kobya, R. D. C. Soltani, P. I. Omwene, and A. Khataee, "A review on decontamination of arsenic-contained water by electrocoagulation: reactor configurations and operating cost along with removal mechanisms," Environmental Technology \& Innovation, vol. 17, article 100519, 2020.
[3] X. He, F. Deng, T. Shen et al., "Exceptional adsorption of arsenic by zirconium metal-organic frameworks: engineering exploration and mechanism insight," Journal of Colloid and Interface Science, vol. 539, pp. 223-234, 2019.

[4] P. S. Kumar, R. Q. Flores, C. Sjöstedt, and L. Önnby, “Arsenic adsorption by iron-aluminium hydroxide coated onto macroporous supports: insights from X-ray absorption spectroscopy and comparison with granular ferric hydroxides," Journal of Hazardous Materials, vol. 302, pp. 166-174, 2016.

[5] T. H. Nguyen, H. N. Tran, H. A. Vu et al., "Laterite as a lowcost adsorbent in a sustainable decentralized filtration system to remove arsenic from groundwater in Vietnam," Science of Total Environment, vol. 699, article 134267, 2020.

[6] Y. Salameh, A. B. Albadarin, S. Allen, G. Walker, and M. N. M. Ahmad, "Arsenic(III,V) adsorption onto charred dolomite: charring optimization and batch studies," Chemical Engineering Journal, vol. 259, pp. 663-671, 2015.

[7] Z. Cheng, F. Fu, D. D. Dionysiou, and B. Tang, "Adsorption, oxidation, and reduction behavior of arsenic in the removal of aqueous As(III) by mesoporous Fe/Al bimetallic particles," Water Research, vol. 96, pp. 22-31, 2016.

[8] Z. Wen, Y. Zhang, X. Zhou, and R. Chen, "Effective As(III) and $\mathrm{As}(\mathrm{V})$ immobilization from aqueous solution by nascent ferrous hydroxide colloids (FHC)," Separation and Purification Technology, vol. 176, pp. 395-401, 2017.

[9] C. Zhu and G. Yang, "Insights from the adsorption of halide ions on graphene materials," ChemPhysChem, vol. 17, no. 16, pp. 2482-2488, 2016.

[10] H. N. Tran, S.-J. You, A. Hosseini-Bandegharaei, and H.P. Chao, "Mistakes and inconsistencies regarding adsorption of contaminants from aqueous solutions: a critical review," Water Research, vol. 120, pp. 88-116, 2017.

[11] X. Yuan, Y. Wang, J. Wang, C. Zhou, Q. Tang, and X. Rao, "Calcined graphene/MgAl-layered double hydroxides for enhanced $\mathrm{Cr}(\mathrm{VI})$ removal," Chemical Engineering Journal, vol. 221, pp. 204-213, 2013.

[12] T. Budinova, D. Savova, B. Tsyntsarski et al., "Biomass waste-derived activated carbon for the removal of arsenic and manganese ions from aqueous solutions," Applied Surface Science, vol. 255, no. 8, pp. 4650-4657, 2009.

[13] S. Wang, B. Gao, A. R. Zimmerman et al., "Removal of arsenic by magnetic biochar prepared from pinewood and natural hematite," Bioresource Technology, vol. 175, pp. 391-395, 2015.

[14] Z. Zhou, Y.-g. Liu, S.-b. Liu et al., "Sorption performance and mechanisms of arsenic $(\mathrm{V})$ removal by magnetic gelatinmodified biochar," Chemical Engineering Journal, vol. 314, pp. 223-231, 2017.

[15] M. K. Uddin, "A review on the adsorption of heavy metals by clay minerals, with special focus on the past decade," Chemical Engineering Journal, vol. 308, pp. 438-462, 2017.

[16] S. Wan, S. Wang, Y. Li, and B. Gao, "Functionalizing biochar with $\mathrm{Mg}-\mathrm{Al}$ and $\mathrm{Mg}$-Fe layered double hydroxides for removal of phosphate from aqueous solutions," Journal of Industrial and Engineering Chemistry, vol. 47, pp. 246-253, 2017.

[17] C. M. Navarathna, A. G. Karunanayake, S. R. Gunatilake et al., "Removal of Arsenic(III) from water using magnetite precipitated onto Douglas fir biochar," Journal of Environmental Management, vol. 250, article 109429, 2019.

[18] Y. Wang, Z. Liu, Y. Li et al., "Umbellate distortions of the uranyl coordination environment result in a stable and porous 
polycatenated framework that can effectively remove cesium from aqueous solutions," Journal of the American Chemical Society, vol. 137, no. 19, pp. 6144-6147, 2015.

[19] Y. Jia, Y. Zhang, J. Fu et al., "A novel magnetic biochar/MgFelayered double hydroxides composite removing $\mathrm{Pb}^{2+}$ from aqueous solution: isotherms, kinetics and thermodynamics," Colloids and Surfaces a-Physicochemical and Engineering Aspects, vol. 567, pp. 278-287, 2019.

[20] H. N. Tran, D. T. Nguyen, G. T. Le et al., “Adsorption mechanism of hexavalent chromium onto layered double hydroxides-based adsorbents: a systematic in-depth review," Journal of Hazardous Materials, vol. 373, pp. 258-270, 2019.

[21] R. E. Daugherty, M. M. Zumbach, S. F. Sanders, and T. D. Golden, "Design challenges in electrodepositing metalanionic clay nanocomposites: synthesis, characterization, and corrosion resistance of nickel-LDH nanocomposite coatings," Surface \& Coatings Technology, vol. 349, pp. 773-782, 2018.

[22] T. Aradi, V. Hornok, and I. Dekany, "Layered double hydroxides for ultrathin hybrid film preparation using layer-by-layer and spin coating methods," Colloids and Surfaces aPhysicochemical and Engineering Aspects, vol. 319, no. 1-3, pp. 116-121, 2008.

[23] S. Ma, C. Fan, L. Du et al., "Intercalation of macrocyclic crown ether into well-crystallized LDH: formation of staging structure and secondary host-guest reaction," Chemistry of Materials, vol. 21, no. 15, pp. 3602-3610, 2009.

[24] L. Valeikiene, M. Roshchina, I. Grigoraviciute-Puroniene et al., "On the reconstruction peculiarities of sol-gel derived $\mathrm{Mg}_{2}$ ${ }_{\mathrm{x}} \mathrm{M}_{\mathrm{x}} / \mathrm{A}_{1}(\mathrm{M}=\mathrm{Ca}, \mathrm{Sr}, \mathrm{Ba})$ layered double hydroxide," Crystals, vol. 10, no. 6, pp. 1-20, 2020.

[25] X. L. Guo, X. Y. Liu, X. D. Hao et al., "Nickel-manganese layered double hydroxide nanosheets supported on nickel foam for high-performance supercapacitor electrode materials," Electrochimica Acta, vol. 194, pp. 179-186, 2016.

[26] A. Alahabadi, P. Singh, P. Raizada et al., "Activated carbon from wood wastes for the removal of uranium and thorium ions through modification with mineral acid," Colloids and Surface A: Physicochemical and Engineering Aspects, vol. 607, no. 20 , article 125516, 2020.

[27] Y. Li, Q. Du, T. Liu et al., "Methylene blue adsorption on graphene oxide/calcium alginate composites," Carbohydrate Polymers, vol. 95, no. 1, pp. 501-507, 2013.

[28] E. Otgonjargal, Y. S. Kim, S. M. Park, K. Baek, and J. S. Yang, "Mn-Fe layered double hydroxides for adsorption of As(III) and As(V)," Separation Science and Technology, vol. 47, no. 14-15, pp. 2192-2198, 2012.

[29] M. B. Ali, F. Wang, R. Boukherroub, and M. Xia, "High performance of phytic acid-functionalized spherical polyphenylglycine particles for removal of heavy metal ions," Applied Surface Science, vol. 518, article 146206, 2020.

[30] H. R. Nodeh, W. A. W. Ibrahim, I. Ali, and M. M. Sanagi, "Development of magnetic graphene oxide adsorbent for the removal and preconcentration of As(III) and As(V) species from environmental water samples," Environmental Science and Pollution Research, vol. 23, no. 10, pp. 9759-9773, 2016.

[31] Z. Wei, Z. Wang, J. Yan et al., "Adsorption and oxidation of arsenic by two kinds of $\beta-\mathrm{MnO}_{2}$," Journal of Hazardous Materials, vol. 373, no. 5, pp. 232-242, 2019.

[32] T. Wang, C. Li, C. Wang, and H. Wang, "Biochar/MnAl-LDH composites for $\mathrm{Cu}(I I)$ removal from aqueous solution," Col- loids and Surfaces A: Physicochemical and Engineering Aspects, vol. 538, no. 5, pp. 443-450, 2018.

[33] B. Zhou, X. Wei, Y. Wang, Q. Huang, B. Hong, and Y. Wei, "Effect of lanthanum addition on microstructures and corrosion behavior of ZnAl-LDHs film of 6061 aluminum alloys," Surface \& Coatings Technology, vol. 379, article 125056, 2019.

[34] T. Sun, Z. Zhang, J. Xiao et al., "Facile and green synthesis of palladium nanoparticles-graphene-carbon nanotube material with high catalytic activity," Scientific Reports, vol. 3, no. 1, p. 2527, 2013.

[35] S. Bang, M. D. Johnson, G. P. Korfiatis, and X. Meng, "Chemical reactions between arsenic and zero-valent iron in water," Water Research, vol. 39, no. 5, pp. 763-770, 2005.

[36] Y. Wang, L. Wang, T. Tian, X. Hu, C. Yang, and Q. Xu, “Automated solid-phase extraction hyphenated to voltammetry for the determination of quercetin using magnetic nanoparticles and sequential injection lab-on-valve approach," Analyst, vol. 137, no. 10, pp. 2400-2405, 2012.

[37] L. Guo, X. Zhang, Q. Chen, C. Ruan, and Y. Leng, "Enhanced removal performance by the core-shell zeolites/MgFe-layered double hydroxides (LDHs) for municipal wastewater treatment," Environmental Science and Pollution Research, vol. 23, no. 7, pp. 6749-6757, 2016.

[38] D. Ociński, I. Jacukowicz-Sobala, P. Mazur, J. Raczyk, and E. Kociołek-Balawejder, "Water treatment residuals containing iron and manganese oxides for arsenic removal from water - characterization of physicochemical properties and adsorption studies," Chemical Engineering Journal, vol. 294, pp. 210-221, 2016.

[39] D. Ociński, I. Jacukowicz-Sobala, J. Raczyk, and E. KociołekBalawejder, "Evaluation of hybrid polymer containing iron oxides as As(III) and As(V) sorbent for drinking water purification," Reactive \& Functional Polymers, vol. 83, pp. 24-32, 2014.

[40] I. Andjelkovic, D. N. H. Tran, S. Kabiri, S. Azari, M. Markovic, and D. Losic, "Graphene aerogels decorated with $\alpha$-FeOOH nanoparticles for efficient adsorption of arsenic from contaminated waters," ACS Applied Materials \& Interfaces, vol. 7, no. 18 , pp. 9758-9766, 2015.

[41] L. Zhang, S. Tang, C. Jiang, X. Jiang, and Y. Guan, "Simultaneous and efficient capture of inorganic nitrogen and heavy metals by polyporous layered double hydroxide and biochar composite for agricultural nonpoint pollution control," ACS Applied Materials \& Interfaces, vol. 10, no. 49, pp. 4301343030, 2018.

[42] S. Kumar, R. R. Nair, P. B. Pillai, S. N. Gupta, M. A. R. Iyengar, and A. K. Sood, "Graphene oxide- $\mathrm{MnFe}_{2} \mathrm{O}_{4}$ magnetic nanohybrids for efficient removal of lead and arsenic from water," ACS Applied Materials \& Interfaces, vol. 6, no. 20, pp. 17426-17436, 2014.

[43] Y. Wei, S. Wei, C. Liu et al., "Efficient removal of arsenic from groundwater using iron oxide nanoneedle array-decorated biochar fibers with high Fe utilization and fast adsorption kinetics," Water Research, vol. 167, article 115107, 2019.

[44] T. Xiong, X. Yuan, H. Wang et al., "Highly efficient removal of diclofenac sodium from medical wastewater by $\mathrm{Mg} / \mathrm{Al}$ layered double hydroxide-poly(m-phenylenediamine) composite," Chemical Engineering Journal, vol. 366, pp. 83-91, 2019.

[45] S. Wang, B. Gao, and Y. Li, "Enhanced arsenic removal by biochar modified with nickel $(\mathrm{Ni})$ and manganese $(\mathrm{Mn})$ oxyhydroxides," Journal of Industrial \& Engineering Chemistry, vol. 37, pp. 361-365, 2016. 
[46] S. R. Ryu, E. K. Jeon, J. S. Yang, and K. Baek, "Adsorption of $\mathrm{As}(\mathrm{III})$ and $\mathrm{As}(\mathrm{V})$ in groundwater by Fe-Mn binary oxideimpregnated granular activated carbon (IMIGAC)," Journal of the Taiwan Institute of Chemical Engineers, vol. 72, pp. 62-69, 2017.

[47] S. Wang, B. Gao, Y. Li, A. R. Zimmerman, and X. Cao, "Sorption of arsenic onto $\mathrm{Ni} / \mathrm{Fe}$ layered double hydroxide (LDH)biochar composites," RSC Advances, vol. 6, no. 22, pp. 17792-17799, 2016.

[48] A. B. Gabriella, G. M. D. Ferreira, K. P. F. Siqueira et al., "Adsorption of organic and inorganic arsenic from aqueous solutions using MgAl- LDH with incorporated nitroprusside," Journal of Colloid and Interface Science, vol. 575, pp. 194-205, 2020.

[49] K. Taleb, J. Markovski, Z. Veličković et al., “Arsenic removal by magnetite-loaded amino modified nano/microcellulose adsorbents: effect of functionalization and media size," Arabian Journal of Chemistry, vol. 12, no. 8, pp. 4675-4693, 2019.

[50] N. Zhu, T. Yan, J. Qiao, and H. Cao, “Adsorption of arsenic, phosphorus and chromium by bismuth impregnated biochar: adsorption mechanism and depleted adsorbent utilization," Chemosphere, vol. 164, pp. 32-40, 2016.

[51] P. I. R. Moraes, F. Wypych, and A. A. Leitão, "DFT study of layered double hydroxides with cation exchange capacity: $\left(\mathrm{A}^{-}\right.$ $\left.{ }^{+}\left(\mathrm{H}_{2} \mathrm{O}\right)_{6}\right)\left[\mathrm{M}_{6}{ }^{2+} \mathrm{Al}_{3}(\mathrm{OH})_{18}\left(\mathrm{SO}_{4}\right)_{2}\right] \cdot 6 \mathrm{H}_{2} \mathrm{O}\left(\mathrm{M}^{2+}=\mathrm{Mg}, \mathrm{Zn}\right.$ and $\left.\mathrm{A}^{+}=\mathrm{Na}, \mathrm{K}\right)$," The Journal of Physical Chemistry C, vol. 123, no. 15, pp. 9838-9845, 2019. 